\title{
REAL EXCHANGE RATE MISALIGNMENTS: THE CASE OF THE INDONESIAN RUPIAH
}

\author{
Rasbin*, Mohamad Ikhsan**, Beta Y. Gitaharie***, Yoga Affandi**** \\ * Corresponding author. Rasbin: Research Center, Secretary-General of The House of Representative of \\ Republic of Indonesia, Indonesia. Email: rasbin@dpr.go.id \\ ** Faculty of Economics and Business, Department of Economics, University of Indonesia, Indonesia. \\ Email: ican711@yahoo.com \\ *** Faculty of Economics and Business, Department of Economics, University of Indonesia, Indonesia. \\ Email: beta.laksono@yahoo.com \\ **** Group Head at Department of Economic and Monetary Policy, Bank Indonesia, Jakarta, Indonesia. \\ Email: yoga.affandi@gmail.com
}

\begin{abstract}
This paper analyses the equilibrium price of the Indonesian Rupiah using the Synthetic Control Method (SCM) and assesses its misalignments. We find evidence of Rupiah misalignment, as the currency was undervalued for most periods, except for 19931996. This finding is robust across model specifications, predictors, and weighting. Our finding implies that keeping the exchange rate at its equilibrium level is ideal, and that policymakers can take advantage of the undervalued currency to promote economic growth via exports.
\end{abstract}

Keywords: Misalignments; Equilibrium real exchange rate; Real exchange rate; Synthetic control method.

JEL Classifications: C29; F10; F31.

Article history:

Received : February 12, 2020

Revised : October 20, 2020

Accepted : March 15, 2021

Available online : September 30, 2021

https://doi.org/10.21098/bemp.v24i3.1268 


\section{INTRODUCTION}

The determination of equilibrium exchange rates and the study of exchange rate misalignments support central banks' objectives of achieving price stability and maintaining a stable financial system (Kurniati and Hardiyanto, 1999). Exchange rate misalignments tend to deteriorate the macroeconomic stability (De Grauwe and Schnabl, 2008; Berg and Miao, 2010; Haddad and Pancaro, 2010; Auboin and Ruta, 2012). More importantly, a prolonged exchange rate misalignment can endanger the economy, since the pressures to push it towards equilibrium strongly accumulate, thereby causing negative sentiments in the market (Kurniati and Hardiyanto, 1999). The vast literature on the determination of the equilibrium level of exchange rates and misalignment of exchange rate both in developed and developing countries in recent years use various exchange rate models, data sets, and estimation strategy, and the choice of observed countries to improve the predictive performance of the equilibrium exchange rates. ${ }^{1}$ However, the empirical evidence on equilibrium exchange rates have been, at best, mixed (Egert and Halpern, 2005).

As articulated in the literature, there are at least two important limitations with the current modelling and estimation methods. The first drawback is related to the use of only one exchange rate theory (Frankel and Rose, 1995; Kilian and Taylor, 2003; and El-Shagi, Lindner, and von Schweinitz, 2016). There are several disadvantages associated with the use of one theory. For instance, the purchasing power parity approach is unable to capture changes in the economic policy as well as changes in the external environment, such as the flow of trade (Kubota, 2011). However, the estimates from the Fundamental Equilibrium Exchange Rate (FEER) approach depend on the specifications of the macroeconomic model. Additionally, the specifications of the model are highly dependent on the reality of parameters of the relationship between variables in the structural model (Siregar, 2011). Besides, the determinants of the equilibrium exchange rates also tend to experience misalignment (Knedlik and Von Schweinitz, 2012). This condition certainly makes it difficult to determine the equilibrium exchange rate.

Second, the exchange rate is not a policy tool, but an endogenous variable that depends on the dynamics of macroeconomic fundamentals (Ikhsan, 2009). This means that the estimation of exchange rates and omitted variables lead to endogeneity and biased results. In general, previous empirical studies have applied specific methods to overcome the problem of endogeneity. However, there are several limitations associated with the use of these methods, including, the extent to which it is used to overcome endogeneity problems (Chamon et al., 2017).

Therefore, this paper examines the equilibrium real exchange rate, with an attempt to eliminate some of the above-mentioned modelling and estimation concerns in the literature. This paper focuses on Indonesia, an emerging Asian country. In Indonesia, exchange rate fluctuations range from moderate to high, creating high welfare costs such as volatility in domestic prices, risks, uncertainties, and brief investment periods (see Kurniati and Hardiyanto, 1999). Subsequently, it reduces the level of firm profits, which negatively impacts economic growth

1 For a recent study, see Ca'Zorzi et al. (2020). 
(Haddad and Pancaro, 2010). In addition, high exchange rate misalignments reduce economic growth (Aguirre and Calderon, 2005).

This paper develops an empirical model of the exchange rate using the SCM. To the best of our knowledge, this is the first attempt to employ SCM to estimate the equilibrium exchange rate in Indonesia. SCM is a recent econometric tool for comparative studies, where the choice of comparison unit is a systematic data driven procedure (Hannan, 2016). The SCM creates synthetic (artificial) control or comparison units based on their similarity to the treated country before the treatment takes place. This is done based on a weighted average of past observable covariates and past realizations of the outcome variables. The evolution of the actual outcome of the treated unit post-treatment is then compared against the outcome of the synthetic unit, and the difference is interpreted as the treatment effect.

The SCM offers better estimates of treatment effects relative to existing methods for a number of reasons. First, the variables identified by all theories as determinants of the equilibrium exchange rate are included in the SCM approach. This contrasts with the previous studies whereby only selected variables were included in the model in accordance with the theories. For instance, Jeong et al. (2010) applied only variables from the theory of the FEER theory, while Coudert et al. (2012) employed only variables from the BEER theory (El-Shagi et al., 2016). Although the variables from the various theories are included in the model when applying the SCM approach, this approach remains agnostic on the specific determinants of equilibrium exchange rates. Moreover, it also allows the use of several equilibrium exchange rate models as a basis for analysis. Second, the SCM approach prioritizes identification based on treatment effects rather than contemporaneous variables used in explaining exchange rate determinants. The estimation of exchange rate determinants using the treatment effects serves to build a counterfactual, which is suitable in two circumstances. One of them is the need to avoid macroeconomic variables, which are determinants of equilibrium exchange rates that have also experienced misalignment. This is because the counterfactual is not built from misaligned contemporaneous variables. The second circumstance is the presence of endogeneity, whereby the SCM approach can substantially reduce this problem by avoiding the risk of omitting variables and reducing the risk of selection biases. According to Hannan (2016), the key advantage of SCM in addressing this endogeneity problem is that it allows the effect of unobserved confounders to vary with time, as opposed to traditional econometric methods that can deal with only time-invariant unobserved country characteristics. Estimating the equilibrium exchange rates using SCM would thus be a novel way of addressing the endogeneity bias problem in the exchange rates literature.

Therefore, this paper contributes to the strand of exchange rates literature that attempts to address the endogeneity issue due to the selection bias or omitted variable, when estimating equilibrium exchange rates. In particular, this paper differs from El-Shagi et al. (2016) in two ways. First, this study used three types of testing frameworks to test the statistical significance of the counterfactual derived from the synthetic control units, namely placebo test, pre-treatment fit index, and the goodness of the pre-treatment fit. Placebo tests are commonly used in the SCM 
approach to test the significance of synthetic control units according to Abadie et al. (2010). This test verifies the ability of the SCM approach to build counterfactuals of synthetic control units. To complete the placebo test, the validity test against the counterfactual in this study also used the pre-treatment fit index developed by Adhikari and Alm (2016) and Adhikari et al. (2016). Unlike placebo tests that only display graphs, the pre-treatment fit index provides an assessment of the matching quality of the SCM approach in the form of indexes (numbers).

Finally, this paper uses the goodness of pre-treatment fit developed by Ferman et al. (2016). This test is appropriate when there is heteroscedasticity with a finite number of pre-treatment periods. Moreover, this paper carries a robustness check to establish the robustness of the counterfactual of the synthetic control group produced by the SCM approach. Following McClelland and Gault (2017), we evaluate the effects of the choice of outcome lags used as predictors, the choice of other predictors, the length of the pre-treatment year range used to fit the synthetic region, and the method for choosing predictor weights. We use three criteria: sensitivity of the fit between the synthetic state and the treated state outcomes in the pre-treatment period, sensitivity of the synthetic state outcome in the treatment period, and sensitivity of donor state selection.

We use a panel dataset from 1980 to 2018. Predictors of equilibrium exchange rates are divided into three groups, namely macroeconomic, structural, and political. Our estimates confirm evidence of Rupiah misalignment for most periods. Specifically, the Rupiah was undervalued in all periods, except for 1993-1996 period. The finding is robust to the model specification, proxies, and weighting and methods. There are two implications of this conclusion. First, policymakers need to keep the exchange rate at its equilibrium level, Second, the country can take advantage of an undervalued exchange rate as a policy instrument to promote economic growth via exports.

The rest of the paper is organised as follows. Section II explains the data and methodology. Section III presents the results and discussion, while Section IV provides the conclusion.

\section{DATA AND METHODOLOGY}

A. Data

This study uses the real exchange rates in the form of Real Effective Exchange Rate (REER) from CEPII (Centre d'Etudes Prospectives et d'Informations Internationales). The REER uses the base year $2010=100$ for the period $1980-2018$. During this period, there are three exchange rate systems (as treatment/policy/intervention) in Indonesia. First, Indonesia implemented a managed floating exchange rate system with managed floating II between September 1986 and 1992. Managed floating II is a managed floating exchange rate system where the floating element is more dominant than the management element, inversely proportional to Managed Floating I. Second, the managed floating exchange rate system with a crawling band was implemented from 1992 to August 1997. Third, the economic crisis of $1997 / 1998$ in Indonesia led to the implementation of a free-floating exchange rate system on August 14, 1997.

Many country control candidates are included as, known in statistical matching literature, "donor pool", to build synthetic control units. The aim is to 
ensure that the control countries can represent the global economy. These control countries are IMF (International Monetary Fund) member countries that did not experience the treatment on Indonesia. Consistent with El-Shagi et al. (2016), to identify a treatment effect, the outcomes of the untreated countries are not affected by the treatment implemented in the treated country (Indonesia). They are our artificially created counterparts for the treated country, Indonesia. Economically, this implies that the counterfactual for Indonesia does not represent what would have happened in Indonesia when the control countries had been formed without Indonesia being part of it. Besides, the countries used as control countries must have data on the variables used in this study.

The control country candidates in the study were divided into three groups based on the type of treatment. For the first treatment, we used the pre-treatment period 1980 - 1986 to develop a synthetic control unit projected in building the counterfactual from 1987 to 1992 . The control country candidates are countries in the period 1987-1992 that did not implement the managed floating exchange rate system with managed floating II when Indonesia implemented it. ${ }^{2}$ Our control country candidates include 21 developed countries (United States of America, Australia, Austria, the Netherlands, Chile, Denmark, Ireland, Iceland, Israel, Italy, Japan, Germany, Canada, Portugal, France, Singapore, Cyprus, Spain, Sweden, Uruguay, and Greece) as well as nine developing countries namely Bolivia, Brazil, the Philippines, Cameroon, Costa Rica, Malaysia, Mexico, Pakistan, and Tunisia.

For the second treatment, our study used the pre-treatment period $1980-$ 1992 to build a synthetic control unit projected in building counterfactual from 1993 to 1997. The control country candidates are countries in the period 19931997 that did not implement the managed floating exchange rate system with a crawling band, but Indonesia implemented it. Our candidate control countries include 17 developed countries, namely the United States of America, Australia, Austria, the Netherlands, Denmark, Finland, England, Japan, Germany, Norway, Portugal, France, New Zealand, Cyprus, Spain, Sweden, and Greece as well as five developing countries namely, South Africa, Cameroon, Ghana, Malaysia, and Venezuela.

Finally, the pre-treatment period 1980 - 1997 was used for third treatment in building synthetic control units projected in constructing counterfactuals from 1998 to 2018. The control country candidates are countries in the period $1998-$ 2018 that did not experience the economic crisis 1997/1998 or implemented a freefloating exchange rate system but Indonesia did. Our candidate control countries include United States of America, Australia, Bahrain, the Netherlands, Denmark, England, Iceland, Israel, Italy, Japan, Germany, Canada, Norway, New Zealand, Spain, Sweden, Switzerland, and Uruguay, as well as seven developing countries namely South Africa, Brazil, India, Iran, Cameroon, Mexico, and Pakistan.

The predictors of the real exchange rate used in this study were chosen based on the theories of the equilibrium exchange rate as well as based on El-Shagi et al. (2016). The predictor group is divided into three, namely macroeconomic, structural, and political variables, as shown in Table 1.

2 For the history of the implementation of the exchange rate system of every country in the world, see Reinhart and Rogoff (2002). 
Table 1.

\section{Matching Criteria Variables and Sources}

This table provides detail data description of all variables considered in this study. Notes: CEPII for Centre d'Etudes Prospectives et d'Informations Internationales, WEO stands for World Economic Outlook, WDI for World Development Indicators, and EFW for Economic Freedom of the World.

\begin{tabular}{lcc}
\hline No. & Variable & Data Source \\
\hline 1. & REER & CEPII \\
2. & Macroeconomic variables & WEO \\
& a. Per capita GDP & WEO \\
& b. Growth of per capita GDP & WEO \\
c. Capital Formation & WDI \\
d. FDI/GDP & WEO \\
& e. Current Account & WDI \\
& f. Inflation & \\
Structural variables & WDI \\
a. Export/GDP & WDI \\
b. Trade/GDP & \\
Political variables & EFW \\
4. & a. Size of Government Sector & EFW \\
& b. Trade Barriers & EFW \\
& c. Credit Regulations & EFW \\
& d. Regulation & EFW \\
\hline
\end{tabular}

\section{B. Methodology}

Real exchange rate misalignment is defined as the difference between the actual and the equilibrium real exchange rates. Following El-Shagi et al. (2016), the equilibrium real exchange rate was obtained using the SCM approach in the form of a synthetic real exchange rate (synthetic control group). This approach was made by Abadie and Gardeazabal (2003) and developed by Abadie et al. (2010, 2015).

Technical details of the SCM of Abadie et al. (2010) are as follows: let $E_{i t}{ }^{N}$ be the real exchange rate for country $i$ in period $t$ in the absence of the policy intervention and $E_{i t}{ }^{I}$ the corresponding value for the treated country during the implementation period or post-treatment periods, $\left[T_{0}+1, \ldots, T\right]$. Assuming that the real exchange rate before the implementation period or pre-treatment periods is not affected by the treatment. Therefore, for $t \in\left[1, \ldots, T_{0}\right]$ or pre-treatment periods and $i \in[1, \ldots, N]$, $E_{i t}{ }^{N}=E_{i t}{ }^{I}$ is applied. However, the real exchange rate during the implementation period or post-treatment periods is affected by the treatment, so $E_{i t}{ }^{N} \neq E_{i t}{ }^{I}$ is applied for $t \in\left[T_{0}+1, \ldots, T\right]$. Suppose $\alpha_{i t}$ is the difference in the real exchange rate during the post-treatment periods between the treated country and synthetic control countries (untreated countries), $\alpha_{i t}=E_{i t}^{I}-E_{i t}^{N}, \alpha_{i t} \lesseqgtr 0$. During the implementation period, we applied the formula $\alpha_{1 t}=E_{1 t}{ }^{I}-E_{1 t}{ }^{N}=E_{1 t}-E_{1 t}{ }^{N}$. The variable $E_{1 t}{ }^{I}$ is the observed real exchange rate, therefore, we estimate $E_{1 t}{ }^{N}$.

Suppose $E_{i t}{ }^{N}$ can be expressed as:

$$
E_{i t}^{N}=\vartheta_{0 t}+\vartheta_{1 t} A_{i}+\vartheta_{2 t} B_{i}+\vartheta_{3 t} C_{i}+\mu_{t} \lambda_{i}+\varepsilon_{i t}
$$


where $\vartheta_{0 t}$ is a time fixed effect. The vectors $A_{i t^{\prime}} B_{i t^{\prime}}$ and $C_{i t}$ sized $(r \times 1)$ are used to denote the macroeconomic, structural, and political variables. The parameters $\vartheta_{1}, \vartheta_{2}$, and $\vartheta_{3}$ with size $(1 \times r)$ are coefficients of each of these predictors, which affect the real exchange rate. The notation $\varepsilon_{i t}$ is assumed to be random shocks with zero averages and independent between countries and periods. The vector $\mu_{t}$ with size $(1 \times F)$ represents an unobserved time-variant factor that affects the real exchange rate. Besides, the loading factor unknown to each country is described by the coefficient vector $\lambda_{i}$ with size $(F \times i)$, while the observed actual factors are known as latent variables.

The SCM approach chooses the optimal weighting value, $W^{*}$, to produce the best synthetic control unit capable of estimating the real exchange rate variable of a country experiencing a policy intervention. The weighting vector has the dimensions $(J \times 1), W=\left(w_{2}, \ldots, w_{J+1}\right)^{\prime}$ with $w_{i} \geq 0$ for $j=2, \ldots, J+1$ and $\sum_{i=2}^{I} w_{i}=1$. Abadie, Diamond, and Hainmueller (2010) stated that when $E_{1 t}^{N}=\sum_{i=2}^{j+1} w_{i}^{*} E_{i t}$, then $\hat{\alpha}_{1 t}=E_{i t}-\sum_{i=2}^{J+1} w_{i}^{*} E_{i t}$, an estimator of $\alpha_{1 t}$ for the post-treatment period.

The variable $X_{1}$ is used to denote a vector of the characteristics of the exchange rate for the country experiencing a policy intervention in a pre-treatment period containing $E, A, B$, and $C$. The variable $\mathrm{X}_{0}$ is a characteristic vector of the exchange rate for the country/unit control. The value of $W^{*}$ is obtained by minimizing the distance $\left\|X_{1}-X_{0} W\right\|$, between $X_{1}$ and $X_{0} W$ with weighting constraints $\sqrt{\left(X_{1}-X_{0} W\right)^{\prime} V\left(X_{1}-X_{0} W\right)}$. The $V$ matrix is a diagonal weighting matrix containing differences in the elements of the predictor $X_{1}$ and $X_{0}$ by considering the predictive strength of the real exchange rate. The optimal choice of $V$ produces a weight, which minimizes the mean squared error of synthetic control estimators, namely $\left(E_{1}-E_{0} W^{*}\right)^{\prime} V\left(E_{1}-E_{0} W^{*}\right)$. This study uses STATA command synth to produce $V$ vectors. Therefore, the synthetic control group is obtained when the root mean square predictive error (RMSPE) value is at its minimum. It is also obtained when the synthetic control group has a path that is most similar to the outcome variable path of treated unit during the pre-treatment period.

The SCM approach has been extremely popular in recent studies to address endogeneity problems. Abadie et al. (2010) stated that assuming a synthetic unit is discovered such that it matches the trajectory pre-treatment of the outcome variable for the treated unit, the size of the bias is caused by the variation in time. It is unobserved in the difference between the outcome of the variables at post-treatment of treated units and synthetic controls to zero when the period pre-intervention increases. Moreover, the SCM approach also remains robust, even though some macroeconomic variables primarily experience simultaneous imbalances.

To ensure the validity of synthetic real exchange rates of the SCM approach, the study used three types of tests, namely placebo test, pre-treatment fit index, and the goodness of the pre-treatment fit to test the statistical significance of counterfactual analysis derived from the synthetic control units. According to Abadie et al. (2010), placebo tests are used to assume that policy interventions occur in control countries. This study produced a synthetic control unit as a counterfactual for each placebo control. The counterfactual provides significant results, assuming the placebo tests create a different path between Indonesia and other countries. 
The pre-treatment fit index of Adhikari and Alm (2016) and Adhikari et al. (2016) are used to assess whether the synthetic control makes a good counterfactual (Newiak and Willems, 2017). The pre-treatment fit index is formulated as follows:

Fit Index $=\frac{R M S P E}{R M S P E^{a}}$

The RMSPE is derived from the estimates of the SCM approach, where RMSPE $=\sqrt{\frac{1}{T_{0}} \sum_{t=1}^{T_{0}}\left(E_{1 t}-\sum_{j=2}^{J+1} w_{j}^{*} E_{i t}\right)^{2}}$, while RMSPE is RMSPE obtained from the zero-fit model as RMSPE ${ }^{\mathrm{a}}=\sqrt{\frac{1}{T_{0}} \sum_{t=1}^{T_{0}}\left(E_{1 t}\right)^{2}}$. According to Adhikari et al. (2016), the fit index of zero implies a perfect fit, while higher than one indicates a particularly poor fit (Newiak \& Willems, 2017).

According to Ferman et al. (2016), the goodness of pre-treatment fit is used to determine the statistical significance of the counterfactual (see also Ferman and Pinto, 2017). The goodness of pre-treatment fit is formulated as follows:

$$
\tilde{R}^{2}=1-\frac{\frac{1}{T_{0}} \sum_{t=1}^{T_{0}}\left(E_{1 t}-\hat{E}_{1 t}\right)^{2}}{\frac{1}{T_{0}} \sum_{t=1}^{T_{0}}\left(E_{1 t}-\bar{E}_{1}\right)^{2}}
$$

where $\bar{E}_{1}=\frac{\sum_{t=1}^{T_{0}} E_{1 t}}{T_{0}}$. The pre-treatment fit is useful when the goodness of pretreatment fit approaches one $\left(\tilde{R}^{2} \rightarrow 1\right)$.

A robustness check to synthetic real exchange rates generated by the SCM approach, this study follows McClelland and Gault (2017) and considers three strategies, namely the choice of outcome lags used as predictors, the choice of other predictors, and the method for choosing predictor weights.

The SCM approach has several advantages compared to other estimation methods, which are explained in the introduction section. However, it has some limitations worth noting. First, the weighting values and candidate countries used to construct a synthetic real exchange rate using the SCM approach had no economic interpretation (Abadie et al., 2010). Therefore, the factors causing the exchange rate misalignment using the SCM approach cannot be known. Second, the method does not translate as well to monthly time series. In a monthly series, it is more difficult to develop an accurate control because monthly series tend to be more volatile. This is an issue given that the method is fundamentally reliant on weighted averages. The volatility would only be maintained if all countries had matching patterns of volatility (Stojkov, 2016). Third, the SCM approach assumed that unobserved covariates had a linear additive effect on the outcome variable. However, if the characteristics of treatment and control countries are similar, even when the correct data-generating processes are non-linear, linear models can still provide a good approximation (Kreif et al., 2016). 


\section{MAIN FINDINGS}

This section comprises three subsections. We discuss the fit of the REER in the first subsection, followed by the robustness checks in the second subsection. The final subsection discusses the exchange rate misalignment and its implications.

\section{A. Fit of The Real Effective Exchange Rate}

Figures 1 to 3 show the actual and synthetic real exchange rate as Indonesia implemented the exchange rate system of managed floating with managed floating II and crawling band as well as a free-floating exchange rate system or the economic crises of 1997/1998, respectively. The difference between the Indonesian and the synthetic real exchange rates from 1987 to 1992, as shown in Figure 1, is the magnitude of the difference between actual and equilibrium real exchange rates following the implementation of the managed floating II system. The figure shows that Indonesia's real exchange rate is below the synthetic real exchange rate. This means that during the implementation of the managed floating II system, Indonesia's real exchange rate was undervalued.

\section{Figure 1.}

\section{Development of Indonesia Real Exchange Rate and the Synthetic Real Exchange Rate for Period 1980 - 1992}

This figure plots the Indonesia (actual) and synthetic real exchange rates obtain from the synthetic matching under managed floating II regime over the sample period from 1980 to 1992

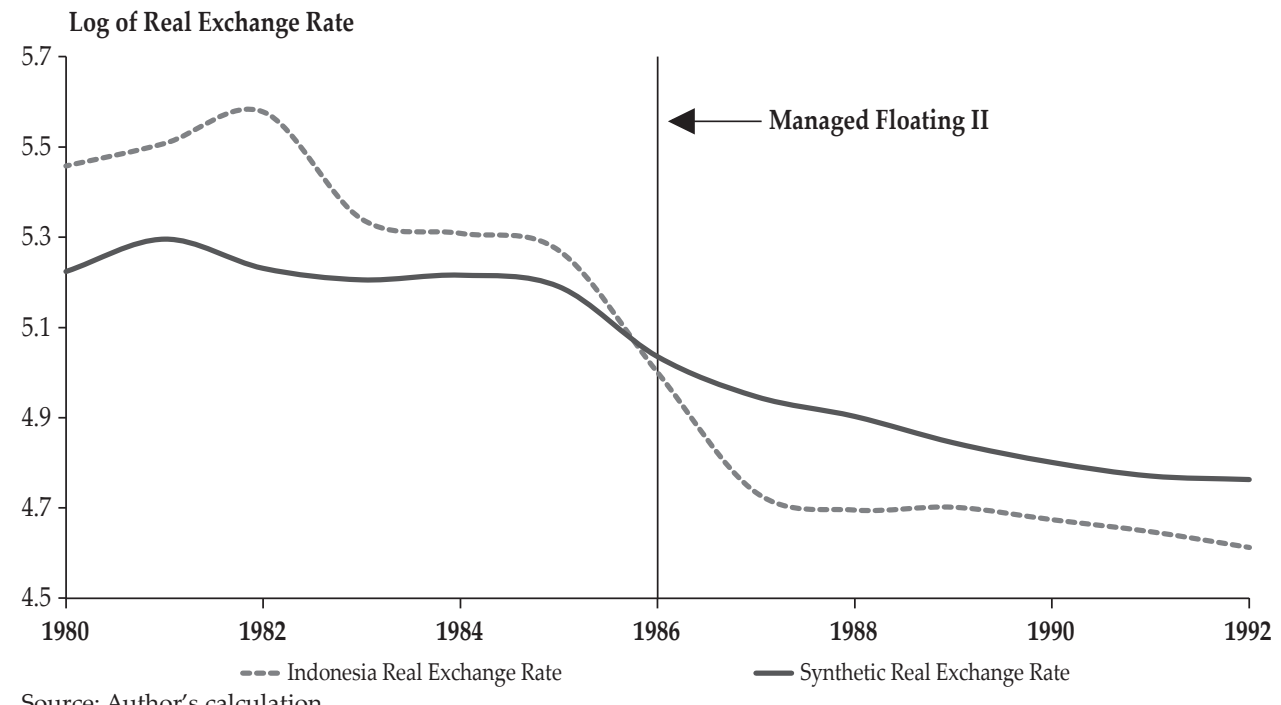

Figure 2 shows that during the crawling band period from 1992 to August 1997, the synthetic and actual real exchange rate had a directional path and converged to a point. The difference between the two lines from 1993 -1997, is the magnitude of the difference between the actual and equilibrium real exchange rate when the during the crawling band regime in Indonesia. The figure show that Indonesia's real exchange rate experienced overvaluation for the period $1993-1997$, except for the period near the economic crisis of 1997/1998. 
Figure 2.

\section{Development of Indonesia Real Exchange Rate and Synthetic Real Exchange Rate Period 1980 - 1997}

This figure plots the equally Indonesia (actual) and synthetic real exchange rate results of synthetic matching of the SCM approach when Indonesia implemented the exchange rate system of crawling band over the sample period from 1980 to 1997.

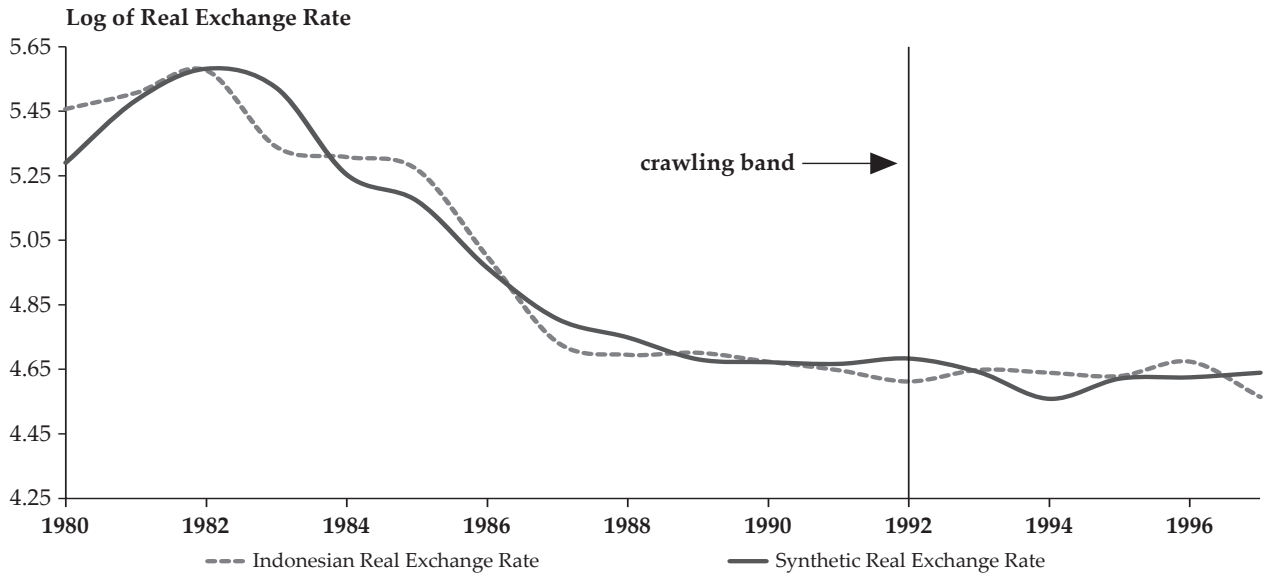

Source: Author's calculation

Figure 3 shows that after the implementation of the free-floating exchange rate system policy, the synthetic and actual real exchange rate were divergent and started converging to a point in 2010. The difference between Indonesia's actual and synthetic real exchange rates from 1998 - 2018 is the magnitude of the difference between the actual real exchange rate and equilibrium real exchange rate during the free-floating exchange rate system. The results show that Indonesia's real exchange rate experienced undervaluation.

Figure 3.

\section{Development of Indonesian Real Exchange Rate and Synthetic Real Exchange Rate Period 1980 - 2018}

This figure plots the equally Indonesia (actual) and synthetic real exchange rate results of synthetic matching of the SCM approach when Indonesia implemented the exchange rate system of free-floating over the sample period from 1980 to 2018.

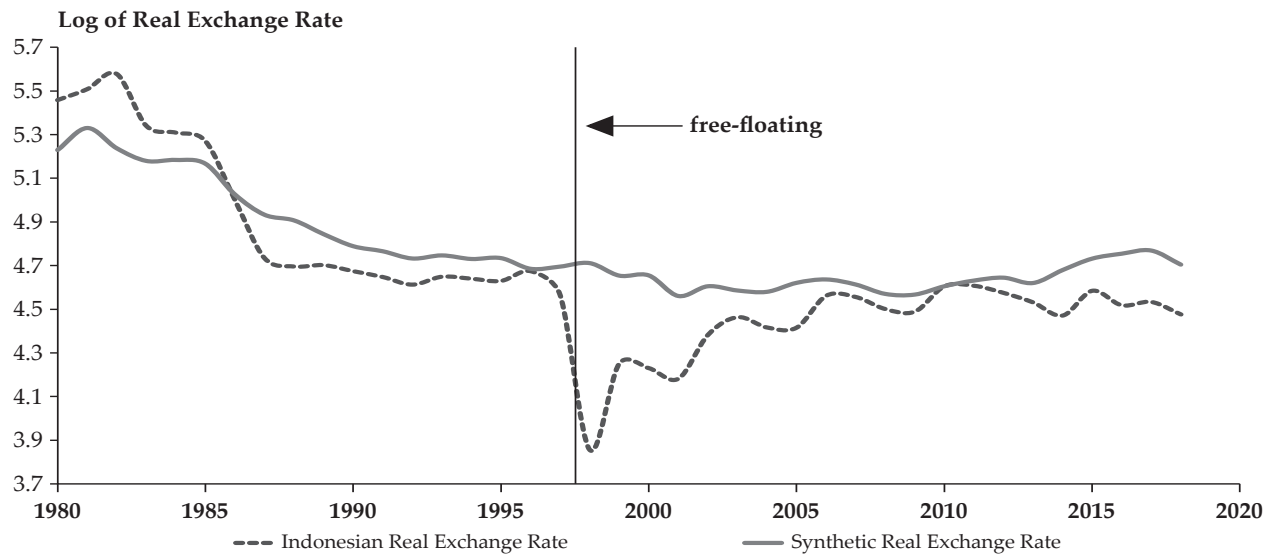


Table 2 reports the estimates of RMSPE for the implementation of each of the three policies or events. Table 3 displays the weights of each control country in the synthetic REER model during the implementation of all three exchange rate regimes in Indonesia. The weights indicate that the development of Indonesia REER prior to implementation of all three policies are best reproduced by a combination of countries in Table 3. However, the weighting values and candidate countries used to construct a synthetic real exchange rate using the SCM approach had no economic interpretation (Abadie et al., 2010).

Table 2.

The Value of RMSPE at the Implementation of the Three Policies

This table reports the value of root mean squared prediction error (RMSPE) for the implementation of each of the three policies or events in Indonesia, namely the managed floating II, crawling band, and free-floating or the economic crisis 1997/1998 regimes. Source: Author's calculation.

\begin{tabular}{lc}
\hline Policies/Events & Value of RMSPE \\
\hline The managed floating II exchange rate system & 0.1904 \\
The crawling band exchange rate system & 0.0834 \\
The free-floating exchange rate system or the economic crisis of 1997/1998 & 0.1477 \\
\hline
\end{tabular}

Source: Author's calculation.

Table 3.

\section{Country Weights in the Synthetic REER at the Implementation of the Three} Policies

This table reports the weighting value and candidate countries used to construct a synthetic REER using the SCM approach.

\begin{tabular}{lcc}
\hline Policies/Events & Country & Weight \\
\hline The managed floating II exchange rate system & Malaysia & 0.288 \\
& Pakistan & 0.712 \\
& Ghana & 0.232 \\
The crawling band exchange rate system & Venezuela & 0.131 \\
& Malaysia & 0.637 \\
The free-floating exchange rate system or the & Pakistan & 0.893 \\
economic crisis of 1997/1998 & India & 0.107 \\
\hline
\end{tabular}

Source: Author's calculation.

The placebo tests of Abadie et al. (2010) were used to evaluate the counterfactual validity of the synthetic control group and the results are displayed in Figures 4 to 6 . The results of the placebo tests for the managed floating II regime (Figure 4) show that the counterfactual real exchange rate of the synthetic control group is statistically significant. Figures 5 and 6 show placebo test results for the crawling band and free-floating or the economic crisis of 1997/1998, respectively. As indicated by Table 4, these results are less conclusive. However, the synthetic real exchange rate with the SCM approach remains valid because the value of the pretreatment fit index is still below one and the goodness of pre-treatment fit value is close to one. 


\section{Placebo Test Results: The Implementation of the Exchange Rate System of Managed Floating II}

This figure shows difference in synthetic and actual real exchange rate for rupiah and 30 placebo countries before and after implementation of the exchange rate system of managed floating II. The grey line represents the difference between the actual real exchange rate and synthetic control groups of each country carried out in the placebo tests, the black line used to represent Indonesia.

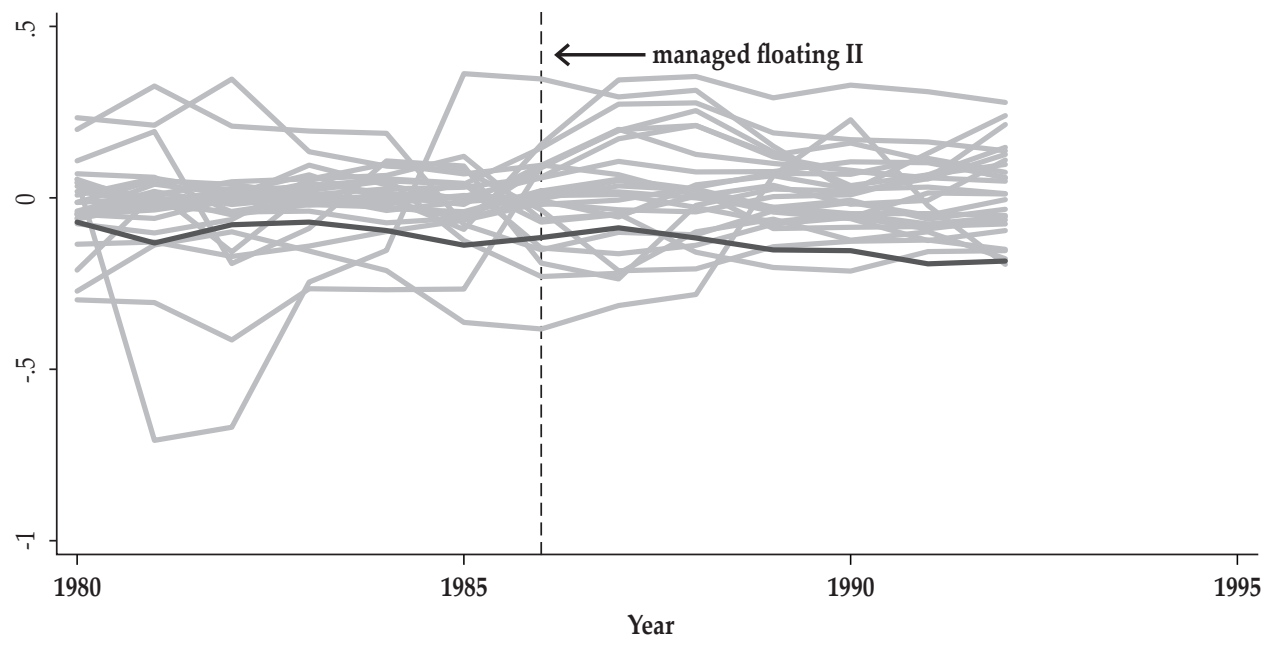

Source: Author's calculation

Figure 5 .

Placebo Test Results: The Implementation of the Exchange Rate System of Crawling Band

This figure shows difference in synthetic and actual real exchange rate for rupiah and 22 placebo countries before and after implementation of the exchange rate system of crawling band. The grey line represents the difference between the actual real exchange rate and synthetic control groups of each country carried out in the placebo tests, the black line used to represent Indonesia.

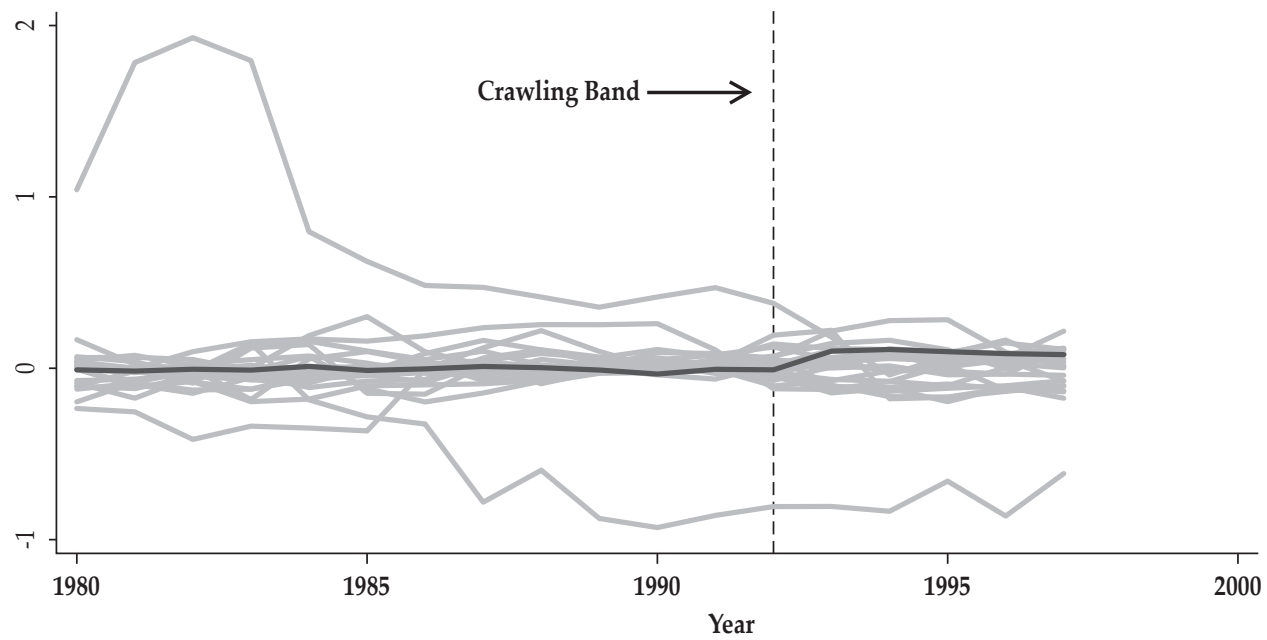

Source: Author's calculation 
Figure 6. Placebo Test Results: The Implementation of the Exchange Rate
System of Free-floating or the Economic Crisis 1997/1998

This figure shows difference in synthetic and actual real exchange rate for rupiah and 25 placebo countries before and after implementation of the exchange rate system of free-floating or the economic crisis 1997/1998. The grey line represents the difference between the actual real exchange rate and synthetic control groups of each country carried out in the placebo tests, the black line used to represent Indonesia.

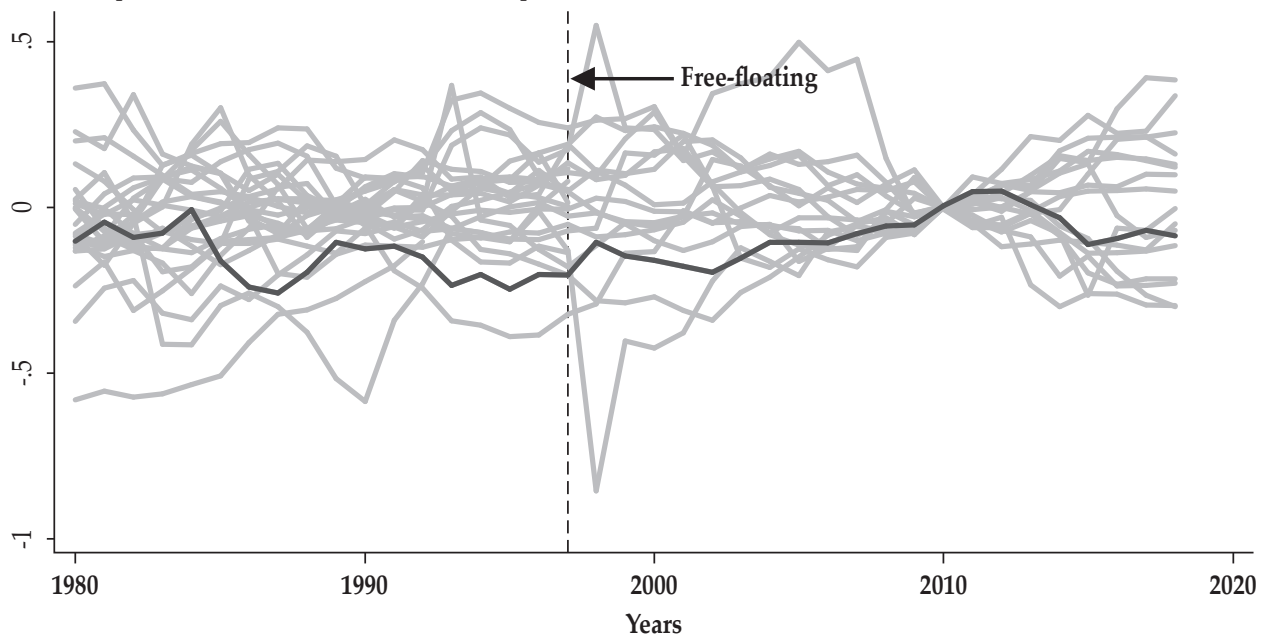

Source: Author's calculation

In addition to the placebo tests, the counterfactual validity test results using the pre-treatment index are displayed in Table 4 . The pre-treatment fit index under the managed floating II, crawling band, and free-floating or the economic crisis of 1997/1998 are $0.574,0.174$, and 0.36, respectively. These values are below one, meaning that the counterfactual real exchange rate of the synthetic control group is reasonable. That is, the counterfactual of the synthetic control group from the SCM approach based on the pre-treatment fit index is statistically significant.

Table 4.

The Validity Tests of the Synthetic REER at the Implementation of the Three Policies

This table reports the validity tests of the synthetic REER from the SCM approach, namely placebo test, pre-treatment fit index, and the goodness of the pre-treatment fit to test the statistical significance of counterfactual analysis derived from the synthetic control units. Fit is perfect if fit index approaches zero and Fit is good if the goodness of pretreatment fit approaches one

\begin{tabular}{|c|c|c|c|}
\hline Policies/Events & Placebo Test & $\begin{array}{l}\text { Pre- } \\
\text { treatment Fit } \\
\text { Index }\end{array}$ & $\begin{array}{c}\text { The Goodness } \\
\text { of Pre- } \\
\text { treatment Fit }\end{array}$ \\
\hline The managed floating II exchange rate system & Conclusive & $0.574^{*}$ & $0.93^{* *}$ \\
\hline The crawling band exchange rate system & Less Conclusive & $0.174^{*}$ & $0.96^{* *}$ \\
\hline $\begin{array}{l}\text { The free-floating exchange rate system or the } \\
\text { economic crisis of 1997/1998 }\end{array}$ & Less Conclusive & $0.36^{*}$ & $0.66^{* *}$ \\
\hline
\end{tabular}


In addition to placebo tests and pre-treatment fit index, we also evaluate validity of the counterfactual using the goodness of pre-treatment fit. The results of the goodness of the pre-treatment fit test on the counterfactual of the synthetic control group under the managed floating II, crawling band, and free-floating or the economic crisis of 1997/1998 are 0.93, 0.96, and 0.66, respectively (Table 4). Based on this, we concluded that the pre-treatment fit meets the proper criteria and is close to a perfect fit. Besides, the counterfactual of the synthetic control group from the SCM approach is statistically significant.

\section{Table 5.}

\section{The RMSPE Values of the Synthetic REER in the Robustness Checks}

This table reports the values of the RMSPE - one measure of the pre-treatment fit - for the different model choices to assess the robustness of the synthetic REER form the SCM approach under the managed floating II, crawling band, and free-floating or the economic crisis of 1997/1998 regimes.

\begin{tabular}{|c|c|c|c|}
\hline $\begin{array}{l}\text { Types of Robustness } \\
\text { Check }\end{array}$ & $\begin{array}{c}\text { The Managed } \\
\text { Floating II Exchange } \\
\text { Rate System }\end{array}$ & $\begin{array}{c}\text { RMSPE } \\
\text { The Crawling } \\
\text { Band Exchange } \\
\text { Rate System } \\
\end{array}$ & $\begin{array}{l}\text { The Free-floating } \\
\text { Exchange Rate System or } \\
\text { the Economic Crisis }\end{array}$ \\
\hline \multicolumn{4}{|l|}{ Outcome Lags } \\
\hline 1980 & 0.1902 & 0.0834 & 0.1477 \\
\hline 1982 & 0.1920 & 0.0834 & 0.1506 \\
\hline 1984 & 0.1980 & 0.0845 & 0.1477 \\
\hline 1986 & 0.2023 & 0.0834 & 0.1578 \\
\hline 1988 & & 0.0834 & 0.1615 \\
\hline 1990 & & 0.0834 & 0.1615 \\
\hline 1992 & & 0.0834 & 0.1595 \\
\hline 1994 & & & 0.1607 \\
\hline 1996 & & & 0.1595 \\
\hline 1980-1984 average & 0.1979 & 0.0834 & 0.1506 \\
\hline 1980-1986 average & 0.1901 & & 0.1482 \\
\hline 1980-1988 average & & 0.0834 & 0.1565 \\
\hline 1980-1992 average & & 0.0834 & 0.1477 \\
\hline 1980-1994 average & & & 0.1483 \\
\hline 1980-1996 average & & & 0.1586 \\
\hline \multicolumn{4}{|l|}{ Predictor Variables } \\
\hline Ten Predictors + Lags & 0.1931 & 0.0834 & 0.1497 \\
\hline Nine Predictors + Lags & 0.1915 & 0.1000 & 0.1506 \\
\hline Eight Predictors + Lags & 0.2042 & 0.0834 & 0.1558 \\
\hline $\begin{array}{l}\text { Eleven Predictors, No } \\
\text { lags }\end{array}$ & 0.3126 & 0.1158 & 0.1546 \\
\hline Nine Predictors, No lags & 0.3060 & 0.1034 & 0.1622 \\
\hline $\begin{array}{l}\text { Seven Predictors, No } \\
\text { lags }\end{array}$ & 0.3389 & 0.1034 & 0.1705 \\
\hline Five Predictors, No lags & 0.2711 & 0.1052 & 0.1654 \\
\hline $\begin{array}{l}\text { Three Predictors, No } \\
\text { lags }\end{array}$ & 0.2986 & 0.2401 & 0.2732 \\
\hline \multicolumn{4}{|c|}{ Method for Selecting Predictor Weights } \\
\hline Standard & 0.1902 & 0.0896 & 0.1721 \\
\hline Cross-validation & 0.1939 & 0.1103 & 0.1477 \\
\hline
\end{tabular}

Source: Author's calculation 


\section{B. Robustness Checks}

In this section, we present the results of three robustness checks, namely the choice of outcome lags used as predictors, the choice of other predictors, and the method for choosing predictor weights. The three robustness checks are carried out on each treatment. For all robustness checks, the value of the RMSPE for the different model choices is shown in Table 5.

\section{B.1. Outcome Lags}

According to Kaul et al. (2016), including all outcome lags for all pre-treatment periods will render the other predictor variables (averaged over pre-treatment periods) useless. Therefore, in this robustness check, we include different outcome lags in synthetic matching to build the synthetic REER. Thus, this robustness check has the potential to affect the results. For this robustness check, the value of the RMSPE is shown in Table 5. The addition of varying outcome lags in synthetic matching caused the RMSPE value of synthetic matching to increase compared to the RMSPE value of our main results. Based on this, our results are robust to including different outcome lags in the model.

\section{B.2. Non-lag Predictor Variables}

In establishing the synthetic REER, we used several determinants of the exchange rate from all theories of exchange rate determination. To test whether our model is robust, we removed the determinants with the lowest weights in the model one at a time and continued until only a few predictor variables remained. In general, the removal of variables from the model will affect the prediction capabilities of the model. Again, our results are robust to this change. The RMSPE value of the synthetic matching by removing the exchange rate determinants from the model is no better than the RMSPE value of our main results (Table 5).

\section{B.3. Selecting Predictor Weights}

Klößner et al., (2017) states that if the number of predictors exceed the selected donor units when using the cross-validation method, the outcome path can depend on seemingly meaningless differences, such as the order of the units listed in the donor unit. The cross-validation method divides the pre-treatment period into two periods: the training period and the validation period. Based on predictor values during the training period, predictor weights are selected to minimize RMSPE in the validation period. The weight is then used with predictor data in the validation period to create synthetic control (McClelland and Gault, 2017).

For the first intervention, the pre-treatment period was divided into the training period from 1980 to 1982 and the validation period from 1983 to 1986. The pre-treatment period in the second intervention was divided into the training period 1980-1985 and the validation period from 1986 to 1991. Finally, the training and validation period in the third intervention was divided into three groups. First, the training period was 1980-1985 and validation period was 1988-1997. Second, the training period was 1980-1989 and validation period was 1990-1997. Third, the training period was 1980-1991 and validation period was 1992-1997. 
Synthetic matching with cross-validation method in the first and second interventions resulted in a higher RMSPE value than our results, but the RMSPE value in the third intervention was the same (Table 5). In addition to the crossvalidation method, we also use standard methods. Again, our results are still robust compared to synthetic matching with cross-validation methods and standards.

\section{Exchange Rate Misalignment and its Implications \\ C.1. Development of Exchange Rate Misalignment}

The equilibrium real exchange rate (a synthetic real exchange rate) of the SCM approach and the exchange rate misalignment for the period 1987-2018 are shown in Figure 7. The real exchange rate experienced misalignment for the period 1987 - 2018. The real exchange rate was undervalued, except for the period $1993-1996$, when its experienced overvaluation. In summary, the findings of this research and previous studies are presented in Table 6 .

Table 6.

Empirical Studies on Indonesia's Exchange Rate Misalignment

This table reports the findings of this study and several empirical studies on the Rupiah's exchange rate equilibrium and its misalignment. It then compares the findings of this study with previous empirical studies.

\begin{tabular}{lccc}
\hline No. & Periods & This Study & Previous Studies \\
\hline 1. & $1987-1992$ & $\begin{array}{c}\text { SCM approach: } \\
\text { real exchange rate } \\
\text { undervaluation by } \\
12.3-15.0 \text { percent. }\end{array}$ & $\begin{array}{c}\text { 1. Tipoy, Breitenbach, and Zerihun (2017) using the BEER } \\
\text { approach (1980 - 2013): exchange rate undervaluation in } \\
\text { Indonesia by } 5 \text { percent. }\end{array}$ \\
& & 2. Waluyo and Siswanto (1998) using the NATREX approach
\end{tabular}

2. Waluyo and Siswanto (1998) using the NATREX approach and Cointegration Johansen Test: real exchange rate undervaluation of the rupiah.

2. 1993-1997 SCM approach: The real exchange rate overvaluation around $0.77-8.12$ percent. Near the 1997/1998 economic crises, the real exchange rate undervaluation was around 7.47 percent.

3. 1998-2018 SCM approach: the real exchange rate undervaluation around $2.38-85.47$ percent.
1. Jongwanich (2009) found that Indonesia's real exchange rate was overvalued and undervalued when it approached the 1997/1998 economic crisis.

2. Waluyo and Siswanto (1998) using the NATREX approach and the Johansen Cointegration test: the real exchange rate of the rupiah experiences overvalued when the implementation of the crawling band system.

1. Cahyono (2008) using the BEER approach (1999Q1 -2006Q4): Indonesia's exchange rate for the period 2000Q2 - 2002Q1 and 2004Q2 - 2005Q1 experienced an undervaluation of 11.57 and 4.38 percent, respectively.

2. Jongwanich (2009) using the BEER approach (1995Q1 - 2008Q3): the economic crisis of 1997/1998 led undervaluation until 100 percent.

3. Kurniati and Hardiyanto (1999) using the BEER approach (1992M1 - 1998M8): the exchange rate after the 1997/1998 economic crisis experienced undervaluation.

4. Yuki (2015) using the FEER approach (2006 - 2014): Indonesia's exchange rate experienced undervaluation.

5. Tipoy, Breitenbach, and Zerihun (2017) using the BEER approach (1980 - 2013): undervaluation of the Indonesian exchange rates for the period 2008 - 2013 was 6.27. 
Figure 7.

Development of Value of Non Oil \& Gas Exports, REER, and

Misalignment Real Exchange Rate for Period 1987 - 2018

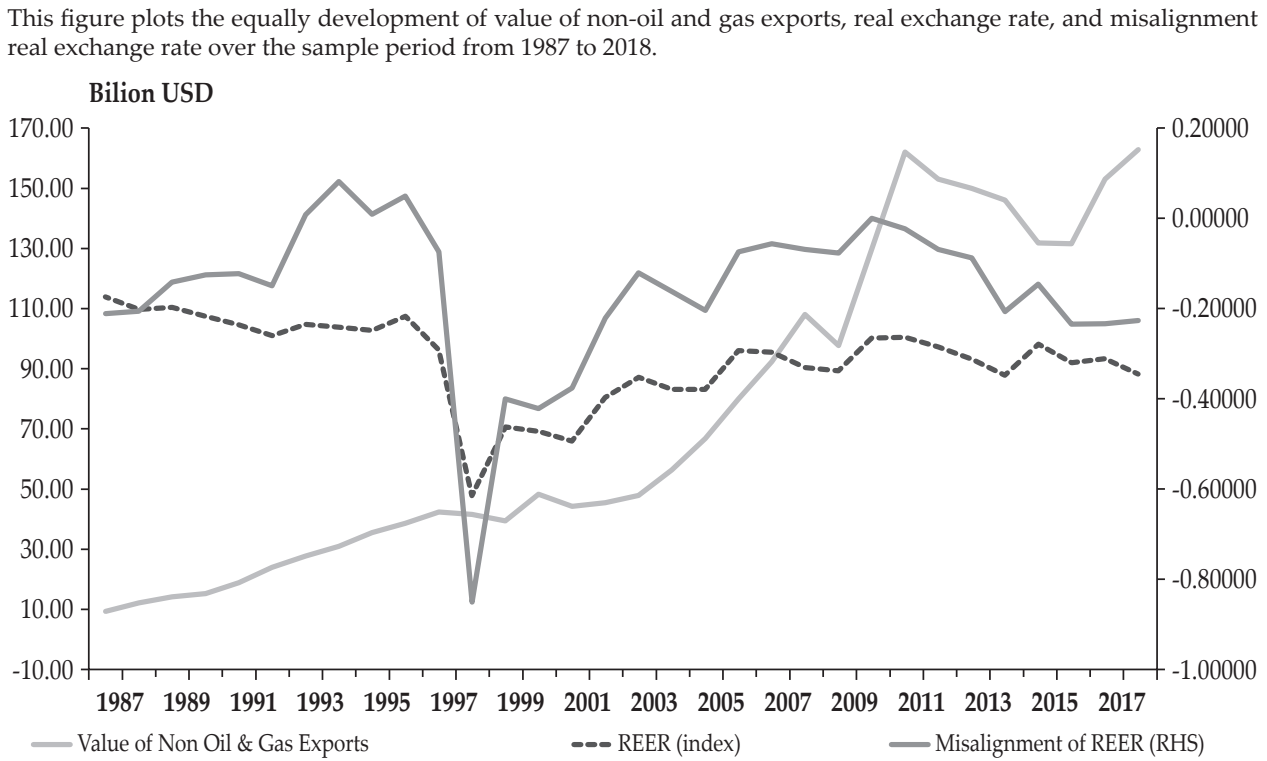

Source: Author's calculation, Statistics Indonesia, and CEPII

The real exchange rate was undervalued by 12.3 - 15.0 percent when Indonesia implemented the managed floating II exchange rate system. This finding is in line with the study conducted by Waluyo and Siswanto (1998) and Tipoy et al. (2017). Tipoy et al. (2017) found that the Rupiah was undervalued by five percent when Indonesia implemented the managed floating II exchange rate system.

The real exchange rate was overvalued by 0.77 - 8.12 percent when Indonesia implemented the crawling band exchange rate system. However, the real exchange rate undervaluation was around 7.47 percent near the economic crisis of 1997/1998. This occurred because the implementation of the crawling band exchange rate system has encouraged increased exchange rate flexibility and the development of the domestic foreign exchange market. This condition resulted in speculative attacks on the exchange rate leading to its decline during the economic crisis of $1997 / 1998$. This finding is in line with studies conducted by Waluyo and Siswanto (1998) and Jongwanich (2009). Jongwanich (2009) found that the real exchange rate was overvalued, but when approaching the economic crisis of 1997/1998 was undervalued. Waluyo and Siswanto (1998) stated that after the managed floating system was implemented with a crawling band, the Rupiah was overvalued. But before the economic crisis of 1997/1998, the Rupiah's real exchange rate was undervalued. However, our results are different from Sahminan (2005), who found that the real exchange rate before the economic crisis of 1997/1998 was overvalued by 40 percent.

Furthermore, when Indonesia implemented the free-floating exchange rate system from 1998 - 2018, the real exchange rate experienced undervaluation by $2.38-85.47$ percent. This finding is in line with previous studies conducted by 
Kurniati and Hardiyanto (1999), Sahminan (2005), Cahyono (2008), Jongwanich (2009), Yuki (2015), and Tipoy, Breitenbach, and Zerihun (2017). Sahminan (2005) found that the Rupiah was undervalued from 1998 - 2003. Besides, Cahyono (2008) found that the exchange rate was undervalued by 11.57 and 4.38 percent for the period 2000Q2 - 2002Q1 and 2004Q2 - 2005Q1, respectively. Our findings are also in line with Jongwanich (2009), who showed the economic crisis of 1997/1998 led to an undervaluation of the Rupiah by 100 percent. Yuki (2015) found that Indonesia's exchange rate was undervalued from 2006 - 2014. Tipoy et al. (2017) found that the exchange rate was undervalued by 6.27 percent for the period 2008 $-2013$.

\section{C.2. The Relationship Between the Real Exchange Rate Misalignment and Exports}

Based on the theory, the exchange rate plays a role in the development of exports and imports. If the currency depreciates or is undervalued, exports and imports will rise and fall, respectively. However, this condition does not always occur because it depends on several factors. In general, the development of Indonesia's non-oil and gas exports is in line with the real exchange rate undervaluation during the managed floating II regime. As shown in Figure 7, the undervaluation of the real exchange rate is relatively followed by an increase in the value of nonoil and gas exports. This finding is in line with the study conducted by Waluyo and Siswanto (1998). Besides exports, a positive relationship also occurs between the undervaluation of the real exchange rate and economic growth, as shown in Figure 8. In developing countries, according to Rodrik (2008), undervaluation of the real exchange rate is relatively followed by an increase in economic growth.

Figure 8.

\section{Development of Economic Growth and Misalignment Real Exchange Rate for Period 1987 - 2018}

This figure plots the equally development of economic growth and misalignment real exchange rate over the sample period from 1987 to 2018 .

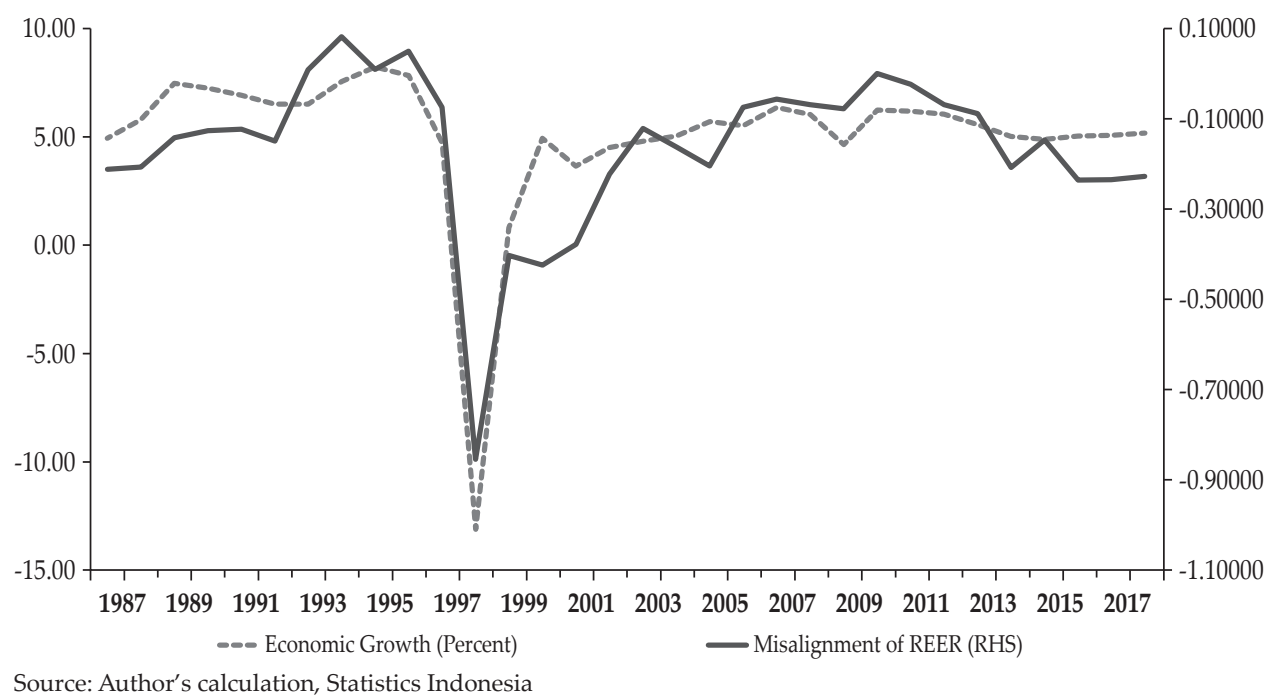


However, contradictions occur during the crawling band exchange rate regime. The exchange rate overvaluation during this period was relatively followed by an increase in the value of non-oil and gas exports, as shown in Figure 7. This fact indicates that the exchange rate overvaluation does not always harm exports. Besides exports, contradictions also occur for economic growth. During the crawling band exchange rate regime, the real exchange rate overvaluation was positively correlated with economic growth, as shown in Figure 8. This finding indicates that economic growth and the value of non-oil exports are not always positively correlated with the undervaluation of the exchange rate, as stated by Rodrik (2008).

After implementing the free-floating exchange rate system, as shown in Figure 7 , the undervaluation of the real exchange rate was relatively followed by an increase in the value of non-oil and gas exports, likewise, with economic growth, consistent with Rodrik (2008). The undervaluation of the exchange rate is relatively followed by an increase in economic growth, as shown in Figure 8 . This finding indicates that the exchange rate can be used as a competitiveness tool to encourage exports and economic growth during the managed floating II and freefloating exchange rate regimes.

\section{C.3. The Relationship Between the Real Exchange Rate Misalignment and Inflation} According to Ikhsan (2009), undervaluation of the real exchange rate will channel imported inflation in the country through an increase in imported products. This condition will cause an increase in domestic inflation. Exchange rate depreciation has a significant contribution to the formation of price changes in Indonesia (Ikhsan, 2009). Therefore, the undervaluation of the real exchange rate will correlate positively with inflation. The relationship between the misalignment of the real exchange rate and inflation under the three different exchange rate systems can be seen in Figure 9.

Figure 9.

\section{Misalignment Real Exchange Rate and Inflation for Period 1987 - 2018}

This figure plots the equally development of inflation and misalignment real exchange rate over the sample period from 1987 to 2018 when Indonesia implements of the exchange rate system of managed floating II, crawling band, and free-floating or the economic crisis 1997/1998.

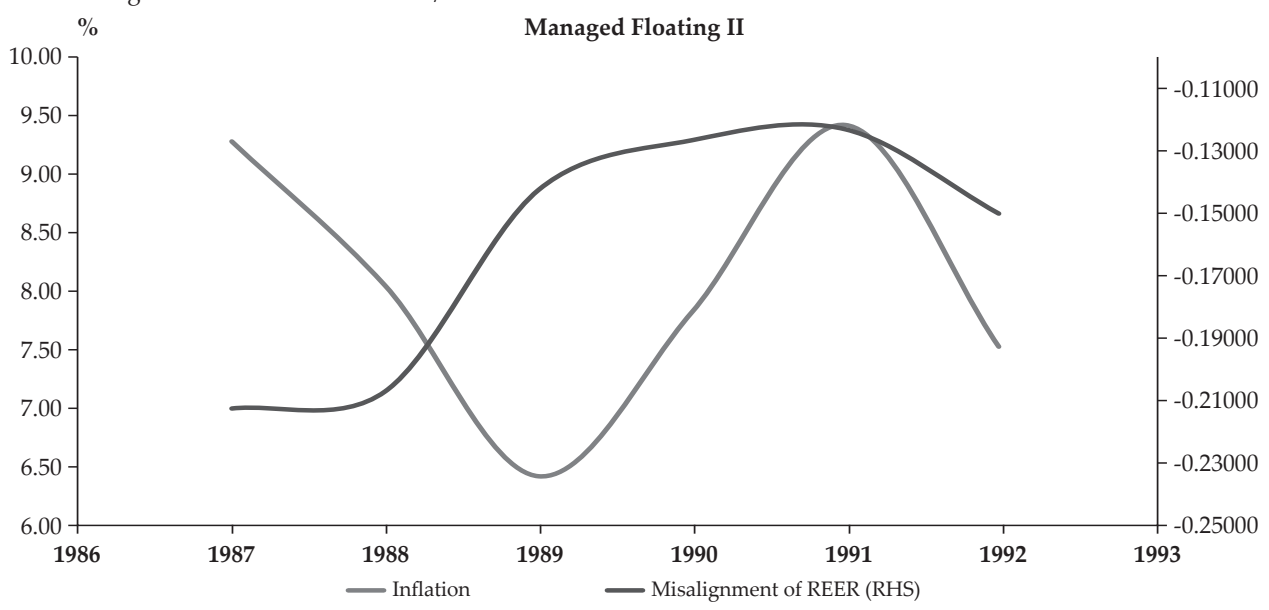


Figure 9.

Misalignment Real Exchange Rate and Inflation for Period 1987 - 2018 (Continued)
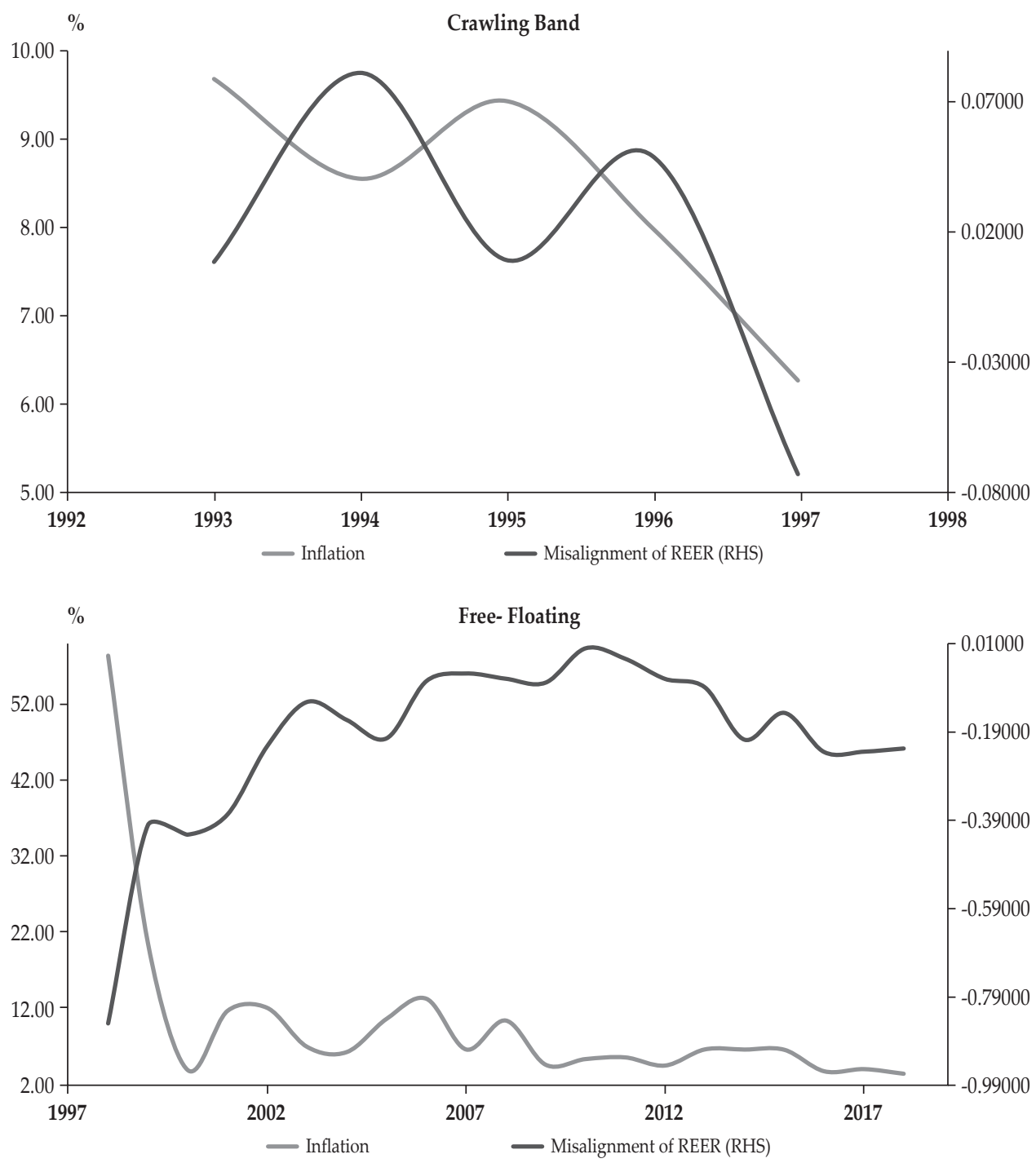

Source: Author's calculation, and Statistics Indonesia

Early in the implementation of the managed floating II exchange rate system, an increase in undervaluation is negatively correlated with inflation. However, a positive correlation between the two variables occurred from 1989 until now. In general, these findings indicate a positive relationship between the undervaluation of the real exchange rate and inflation. Or in other words, the weakening of the real exchange rate has an inflationary impact on domestic prices. According to Waluyo and Siswanto (1998), the Rupiah depreciation period was quite large, and inflationary pressures tended to be high. This condition is due to the surge 
in domestic demand and demand for imports, which in turn put pressure on domestic prices.

\section{CONCLUDING REMARKS}

This paper investigates whether Indonesia's real exchange rate has experienced misalignment under three exchange rate regimes. Annual data from 1980 to 2018 with the SCM approach were used to estimate the equilibrium real exchange rate. The results show that Indonesia's real exchange rate experienced misalignment, particularly being undervalued for the most part of the sample period. This finding is in line with the studies conducted by Waluyo and Siswanto (1998), Kurniati and Hardiyanto (1999), Sahminan (2005), Cahyono (2008), Jongwanich (2009), Yuki (2015), and Tipoy et al. (2017).

The real exchange rate experienced an undervaluation of around $12.3-15.0$ percent from 1987-1992, which is nearly three times the results reported by Tipoy et al. (2017) at 5 percent. Meanwhile, from 1993-1997, the real exchange rate experienced an overvaluation of approximately 0.77 - 8.12 percent, except near the economic crisis of 1997/1998. The real exchange rate was undervalued by 7.47 percent when approaching the economic crisis of 1997/1998. This finding supports Waluyo and Siswanto (1998) and Jongwanich (2009) but contradicts Sahminan (2005). The real exchange rate was undervalued by $2.38-85.47$ percent for the period 1998-2018. This finding is in line with Kurniati and Hardiyanto (1999), Cahyono (2008), Jongwanich (2009), Yuki (2015), and Tipoy et al. (2017). However, the size of the undervaluation we reported is lower than the one reported by Jongwanich (2009) for the economic crisis of 1997/1998.

Besides, this study also confirms that the undervaluation of the real exchange rate is positively correlated with exports, inflation, and economic growth, except under the crawling band exchange rate system. This finding also supports several previous studies, such as Waluyo and Siswanto (1998), Rodrik (2008), and Ikhsan (2009).

However, this paper has several limitations. First, the SCM approach requires long pre-intervention periods. The reason is that the credibility of a synthetic control depends on how well it tracks the treated unit's characteristics and outcomes over an extended period of time prior to the treatment. The length of our pretreatment periods may be short, and the fit of the pre-treatment outcomes might be due to chance. The first treatment in this study, namely the implementation of the managed floating II system, only used pre-treatment periods of 7 years. Second, countries that experience intervention of interest or similar events as the treated country should be excluded from the candidate control countries (donor pool). In the third treatment in this study, we do not exclude countries that experience a free-floating exchange rate system in control countries. Thus, in this sense, our estimates most likely underestimate the truth of the third treatment. Third, in addition to being based on the intervention of interest or similar events, candidates for control countries also should have similar characteristics to the treated countries in order to avoid interpolation bias and overfitting. However, this study included developed countries as candidates for control countries for each intervention of interest. 
Based on these limitations, future research should modify the SCM approach as done by Li (2019) to obtain more accurate estimates. According to Li (2019), when the conventional synthetic control method fits the data poorly, the modified synthetic control method fits the data well and provides reasonable Average Treatment effects estimation results. In addition to the modification of the SCM approach, further research should be conducted by choosing the right intervention of interest. The goal is to get the right control country candidate.

\section{REFERENCES}

Abadie, A., \& Gardeazabal, J. (2003). The Economic Costs of Conflict: A Case Study of the Basque Country. The American Economic Review, 93, 113-132.

Abadie, A., Diamond, A., \& Hainmueller, A. J. (2010). Synthetic Control Methods for Comparative Case Studies: Estimating The Effect of California's Tobacco Control Program. Journal of the American Statistical Association, 105, 493-505.

Abadie, A., Diamond, A., \& Hainmueller, A. J. (2015). Comparative Politics and the Synthetic Control Method. American Journal of Political Science, 59, 495-510.

Adhikari, B., \& Alm, J. (2016). Evaluating the Economic Effects of Flat Tax Reforms Using Synthetic Control Methods. Southern Economic Journal, 83, 437 - 463.

Adhikari, B., Duval, R., Hu, B, \& Loungani, P. (2016). Can Reform Waves Turn the Tide? Some Case Studies the Synthetic Control Method. IMF Working Paper, No. 16/171, 1 - 34 .

Aguirre, A., \& Calderon, C. (2005). Real Exchange Rate Misalignments and Economic Performance. Central Bank of Chile Working Papers, 315, 1-34.

Auboin, M., \& Ruta, M. (2012). The Relationship between Exchange Rates and International Trade: A Literature Review. Cesifo Working Papers, 3868, 1-26. https://papers.ssrn.com/sol3/papers.cfm?abstract_id=2101047

Berg, A., \& Miao, Y. (2010). The Real Exchange Rate and Growth Revisited: The Washington Consensus Strikes Back? IMF Working Paper, No. 10/58, 1-24.

Cahyono, D. (2008). Determinants of Equilibrium Real Exchange Rate and its Misalignment in Indonesia (Post Crisis Era) [Master's Tesis, Institute of Social Studies]. https://www.semanticscholar.org/paper/Determinants-ofEquilibrium-Real-Exchange-Rate-and-Cahyono/8c3944a9ae4bca1467a54bca4a db3c8c9ef66d0f\#citing-papers

Ca'Zorzi, M., Cap, A., Mijakovic, A., \& Rubaszek, M. (2020). The Predictive Power of Equilibrium Exchange Rate Models. ECB Working Papers Series No. 2358, $1-41$.

Chamon, M., Garcia, M., \& Souza, L. (2017). FX Interventions in Brazil: A Synthetic Control Approach. Journal of International Economics, 108, 157-168.

Coudert, V., \& Couharde, C. (2005). Real Equilibrium Exchange Rate in China. CEPII Working Paper, No. 2005-01, 1-44.

Coudert, V., Couharde, C., \& Mignon, V. (2012). On Currency Misalignments within the Euro Area. CEPII Working Paper, No. 2012-07, 1-33.

De Grauwe, P., \& Schnabl, G. (2008). Exchange Rate Stability, Inflation, and Growth in (South) Eastern and Central Europe. Review of Development Economics, 12, 530-549. https://doi.org/10.1111/j.1467-9361.2008.00470.x 
Egert, B., \& Halpern, L. (2005). Equilibrium Exchange Rates in Central and Eastern Europe: A Meta-regression Analysis. William Davidson Institute Working Paper, No. 769, 1-15.

El-Shagi, M., Lindner, A., \& von Schweinitz, G. (2016). Real Effective Exchange Rate Misalignment in the Euro Area: A Counterfactual Analysis. Review of International Economics, 24, 37-66.

Ferman, B., Pinto, C., \& Possebom, V. (2016). Cherry Picking with Synthetic Controls. Textos Para Discussão 420, FGV EESP - Escola de Economia de São Paulo, Fundação Getulio Vargas (Brazil).

Ferman, B., \& Pinto, C. (2017). Placebo Tests for Synthetic Controls Placebo. MPRA Paper, 78079, 1-24.

Frankel, J. A., \& Rose, A. K. (1995). “Empirical Research on Nominal Exchange Rates," in G. M. Grossman and K. Rogoff (eds), Handbook of International Economics (Vol. 3), Amsterdam: North Holland, 1689-1729.

Haddad, M., \& Pancaro, C. (2010). Can Real Exchange Rate Undervaluation Boost Exports and Growth in Developing Countries? Yes, but not for Long. Economic Premise, 20, 1-5.

Hannan, S.A. (2016). The Impact of Trade Agreements: New Approach, New Insights. IMF Working Paper, No. 16/117, 1-32.

Ikhsan, M. (2009). The Effectiveness of the Nominal Exchange Rate as an Instrument to Encourage Non-oil and Gas Exports: A Literature Review (Efektifitas Nilai Tukar Nominal Sebagai Instrumen Untuk Mendorong Ekspor Nonmigas: Tinjauan Literatur). Staff Paper LPEM FEUI, 7, 1-18.

Jeong, S., Mazier, J., \& Saadaoui, J. (2010). Exchange Rate Misalignments at World and European Levels : A FEER Approach. International Economics, 121, 25-58.

Jongwanich, J. (2009). Equilibrium Real Exchange Rate, Misalignment, and Export Performance in Developing Asia. ADB Economics Working Paper Series, No. 151, $1-35$.

Kaul, A., Klößner, S., Pfeifer, G., \& Schieler, M. (2016). Synthetic Control Methods: Never Use All Pre-intervention Outcomes as Economic Predictors. Working Paper. Saarbrücken, Germany: Saarland University.

Kilian, L. \& Taylor, M. P. (2003). Why is it so Difficult to Beat the Random Walk Forecast of Exchange Rates?. Journal of International Economics, 60, 85-107.

Klößner, S., Kaul, A., Pfeifer, G., \& Schieler, M. (2017). Comparative Politics and the Synthetic Control Method Revisited: A Note on Abadie et al. (2015). Working Paper. Saarbrücken, Germany: Saarland University.

Knedlik, T., \& Von Schweinitz, G. (2012). Macroeconomic Imbalances as Indicators for Debt Crises in Europe. Journal of Common Market Studies, 50, 726-745.

Kreif, N., Grieve, R., Hangartner, D., Turner, A. J., Nikolova, S., and Sutton, M. (2016). Examination of the Synthetic Control Method for Evaluating Health Policies with Multiple Treated Units. Health Econ., 25, 1514- 1528.

Kubota, M. (2011). Assessing Real Exchange Rate Misalignments. World Bank Policy Research Working Paper, No. 5925, 1-71.

Kurniati, Y., \& Hardiyanto, A. V. (1999). The Behavior of the Rupiah Exchange Rate and Alternative Calculation of the Real Exchange Rate Equilibrium (Perilaku Nilai Tukar Rupiah dan Alternatif Perhitungan Nilai Tukar Riil Keseimbangan). Buletin Ekonomi Moneter dan Perbankan, 2, 43-76. 
Li, K. T. (2019). Statistical Inference for Average Treatment Effects Estimated by Synthetic Control Methods. Journal of the American Statistical Association. https://doi.org/10.1080/01621459.2019.1686986.

McClelland, R., \& Gault, S. (2017). The Synthetic Control Method as a Tool to Understand State Policy. Washington, DC: Urban-Brookings Tax Policy Center. Retrieved from https://www.urban.org/sites/default/files/publication/89246/ the_synthetic_control_method_as_a_tool_0.pdf

Newiak, M., \& Willems, T. (2017). Evaluating The Impact of Non-Financial IMF Programs Using The Synthetic Control Method. IMF Working Paper, No. 17/109, 1-41.

Reinhart, C. M., \& Rogoff, K. S. (2002). The Modern History of Exchange Rate Arrangements: A Reinterpretation. NBER Working Paper, No. 8963, 1-104.

Rodrik, D. (2008). The Real Exchange Rate and Economic Growth. Brookings Papers on Economic Activity, 39, 365-439.

Sahminan. (2005). Estimating Equilibrium Real Exchange Rates of The Rupiah. Bank Indonesia Working Paper, No. 8, 1-13.

Siregar, R. Y. (2011). The Concepts of Equilibrium Exchange Rate: A Survey of Literature. Staff Paper The SEACEN Centre, No. 81, 1-32.

Stojkov, K. (2016). The Economic Impacts of the Fonterra Whey Protein Concentrate Contamination Incident. [Master's Thesis, Victoria University of Wellington]. https://core.ac.uk/download/pdf/41340199.pdf

Tipoy, C. K., Breitenbach, M. C., \& Zerihun, M. F. (2017). Equilibrium Exchange Rates and Misalignments: The Case of Homogenous Emerging Market Economies. Economic Research Southern Africa of Working Papers, No. 713, 1-26.

Waluyo, D. B., \& Siswanto, B. (1998). The Role of Exchange Rate Policy in the Era of Deregulation and Globalization (Peranan Kebijakan Nilai Tukar dalam Era Deregulasi dan Globalisasi). Buletin Ekonomi Moneter dan Perbankan, 1, 85 - 122.

Yuki, M. (2015). Assessing Asian Equilibrium Exchange Rates as Policy Instruments. RIETI Discussion Paper Series No. 15038, 1 - 39. 